\title{
Sclerosing thymoma: case report
}

Primeira submissão em 14/06/11 Última submissão em 04/04/12

Timoma esclerosante: relato de caso

Gesine Gregorio Siqueira'; Lisley Calixto de Araujo'; Guilherme Cançado Rezende ${ }^{3}$; Nuno Ferreira de Lima ${ }^{4}$; Larissa Cardoso Marinho

\section{key words abstract}

Thymoma

We present a rare case of thymoma in a 36-year old woman, who was initially diagnosed with severe

Sclerosis

myasthenia gravis and subsequently undergone surgical resection. During surgery tumor was found at the anterior mediastinum, tightly attached to the phrenic nerve, pleura and pericardium. Histological

Myasthenia gravis assessment showed large areas of sclerosis and fibrous collagenous tissue as well as islands of epithelial and lymphoid cells. Sclerosing thymoma, which is a rare subtype of thymoma $(<1 \%)$, was diagnosed, thus confirming the first report in Brazil. The patient showed partial improvement of symptoms associated with myasthenia gravis.

resumo

Relatamos um caso raro de timoma em uma mulher de 36 anos de idade, com clínica e diagnóstico de miastenia gravis de difícil controle clínico, submetida à ressecção cirúrgica. No intraoperatório, observou-se tumor no mediastino anterior, firmemente aderido ao nervo frênico, à pleura e ao pericárdio. Ao exame histológico, foram evidenciadas extensas áreas de tecido fibrocolagenoso e esclerose, assim como ilhas de células epiteliais e células linfoides. Diagnosticado timoma esclerosante, subtipo raro de timoma (<1\%), sendo este o primeiro caso relatado no Brasil. A paciente apresentou melhora parcial dos sintomas associados à miastenia gravis.

\section{unitermos}

Timoma

Esclerose

Miastenia gravis

\section{Introduction}

Sclerosing thymoma is a rare tumour $(<1 \%)$ exhibiting the features of a conventional thymoma in terms of epithelial cell morphology and lymphocyte content, but with exuberant collagen-rich stroma ${ }^{(7)}$. Considering its uniqueness, we report a case of sclerosing thymoma in a 36 year-old woman.

\section{Case report}

A 36 year-old female patient has, for six months, bilateral ptosis, reduced muscle strength on the right limbs and dysphagia. The clinic diagnosis of myasthenia gravis was made with the dosage of acetylcholine receptor antibodies at 5,23 $\mathrm{nmol} / \mathrm{l}(<0,2 \mathrm{nmol} / \mathrm{l})$. The clinical treatment with

\footnotetext{
1. Especialista em Patologia.

2. Médica residente de Patologia do Hospital Universitário da Universidade de Brasilia (UnB).

3. Cirurgião torácico.

4. Cirurgião torácico; chefe do serviço de Cirurgia Torácica do Hospital Universitário da UnB.

5. Doutora em Patologia; médica do Hospital Universitário da UnB.
} 
pyridostigmine bromide and prednisone in high doses partially controlled the symptoms.

Chest computed tomography (CT) evidenced an increased and homogeneous thymus. The patient was then indicated for a video-assisted thymectomy with cervical and thoracic approach.

During surgery, the left lobe of the thymus was evidenced firmly attached to the pericardium, pleura and the left phrenic nerve, which required sternotomy. Partial resection of the lesion was performed, including a portion of the pleura and pericardium adhered, preserving the phrenic nerve. The patient had good post operative evolution.

The surgical specimen was formalin-fixed at $10 \%$ and submitted to macroscopic evaluation. Fragments were processed through traditional technique (dehydrated in alcohol, xylene) and embedded in paraffin. Histological sections of $5 \mu \mathrm{m}$ were stained with hematoxylin and eosin.

Immunohistochemical staining was performed by pretreating histological sections in antigen retrieval solution (citrate buffer retrieval solution, $\mathrm{pH} 6$, Dako Laboratories, USA) in a water bath at $98^{\circ} \mathrm{C}$ for 20 minutes and subsequent cooling at room temperature. The following primary antibodies were used: a) monoclonal mouse antihuman CD3, Clone F7.2.38, (Dako Laboratories, USA), working dilution $1: 50$, to identify $T$ cells; $b$ ) monoclonal mouse anti-human CD20cy, Clone L26 (Dako Laboratories, USA), working dilution 1:200, to identify $B$ cells; $C$ ) monoclonal mouse anti-human Cytokeratin, clones AE1/ AE3 (Dako Laboratories, USA) working dilution 1:200 to identify epithelial cells. External control was used for validation of the reaction.

Clinical, laboratory and follow-up data were obtained from medical charts.

At gross examination tumor mass measured $7.5 \times 3.5 \times 1 \mathrm{~cm}$, in pale brown color, firm consistence and hardened areas on the cut surface. Microscopic examination showed extensive areas of fibrocollagen tissue, with hyalinization and sclerosis surrounding islands of epithelial cells without atypia, with interspersed lymphoid cells (Figures 1 and 2). Between the sclerotic areas, we observed cystic degeneration, bone metaplasia, dystrophic calcification and negative images of cholesterol crystals. There were no mitoses or areas of necrosis.

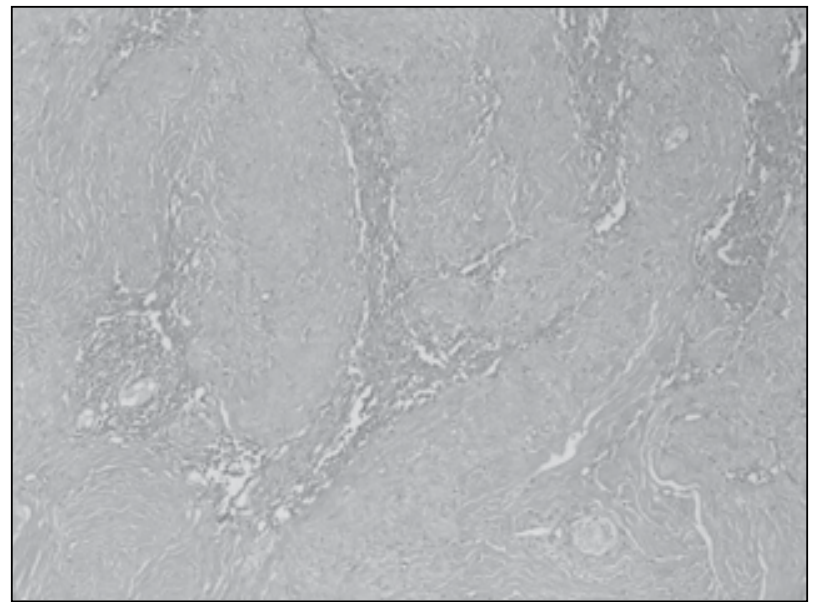

Figure 1 - Sclerosing, thymoma showing areas of fibrocollagen tissue, hialinization and sclerosis surrounding island of epithelial cells HE 100x

HE: hematoxylin and eosin.

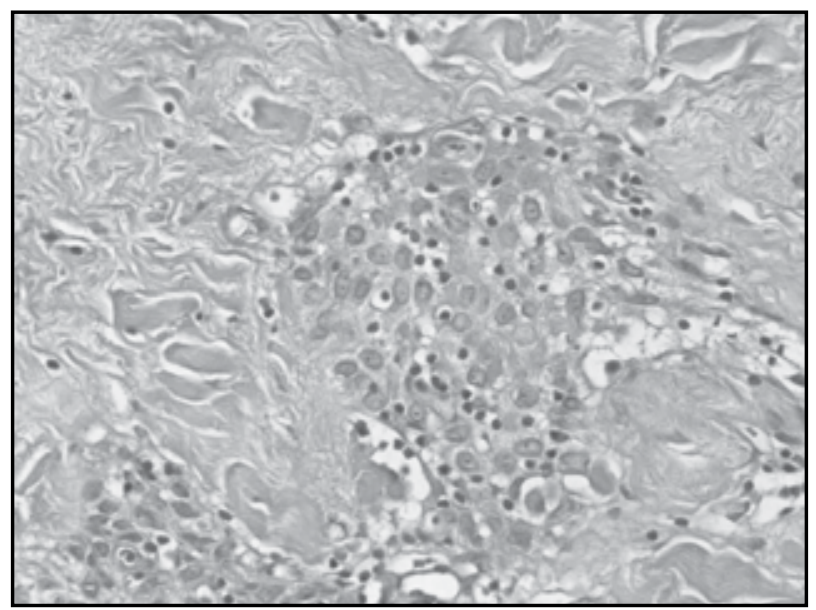

Figure 2 - Islands of epithelial cells without atypia, with interspersed lymphoid cells HE 400x

$H E$ : hematoxylin and eosin.

The immunohistochemal study was performed with antibodies to PanCK, CD3 and CD20, with positive for PanCK in epithelial clusters (Figure 3) and CD3 and CD20 in lymphoid clusters, showing a biphasic marking in the tumor, which lead to confirmation of thymoma, sclerosing subtype according to World Health Organization (WHO).

\section{Discussion}

Sclerosing thymoma is an extremely unusual presentation of thymoma and, including this one, only 13 cases have been reported. This is the first case reported in $\operatorname{Brazil}^{(3,5)}$.

In five cases in the literature, patients were asymptomatic, four were symptomatic (shortness of breath and chest pain) and three had clinical diagnosis of myasthenia gravis. 


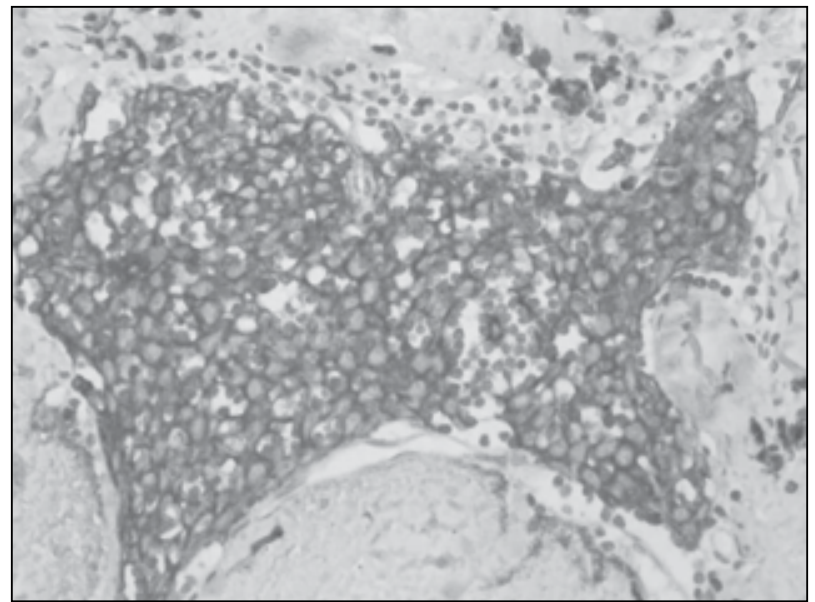

Figure 3 - Positivity for PanCK in epithelial clusters IH, PanCK- 400x

In our case there was a correlation with clinical findings of myasthenia gravis, a fact that was consistent with findings in the report of $\mathrm{Kuo}^{(5)}$ and in only one case in the series of Moran and Suster ${ }^{(5)}$.

Grossly, lesion was poorly demarcated, unencapsulated, pale brown colored and firm consistence with smooth and homogeneous surface. The cut surface was smooth, with areas of crackle and no macroscopic cystic areas, haemorrhage or necrosis were observed. In the literature, the described cases of sclerosing thymoma measured between 2.5 and $10 \mathrm{~cm}$, well defined without bleeding or necrosis ${ }^{(3,5)}$.

Histologically, there were extensive areas of fibrocollagen tissue, with hyalinization and sclerosis, microscopic foci of cystic degeneration, bone metaplasia, dystrophic calcification and negative images of cholesterol crystals. In the midst of those areas we could observe islands of epithelial cells without atypia and lymphoid cells. In our case the complete resection was not possible for being a case of ill-defined lesion adhered to the phrenic nerve, pleura and pericardium.

In Moran and Suster review all thymoma cases had extensive areas of hyalinization or sclerosis, areas of granulomas with cholesterol crystals, calcification and islands of neoplastic epithelial cells. Seven cases of this review, like ours, present dual population of cells (epithelial and lymphoid) without atypia or mitotic activity.

Cases described by $\mathrm{Kuo}^{(3)}$, histology showed small fibrotic and sclerotic nodules, containing predominance of epithelial component at one case and lymphocyte predominance in another. In both, it was observed central hemorrhagic zone, hemosiderin deposits and externally fibrous, sclerotic and dense tissue. It also had areas of calcification and cholesterol granulomas.

After the morphological diagnosis, an immunohistochemical study was performed to highlight the two cellular components: the epithelial one, stained for panCK and $T$ and $B$ lymphoid one, with immunostaining for $C D 3$ and CD 20, respectively. Moran and Suster ${ }^{(5)}$ made an immunohistochemical study for cytokeratin in six of his cases highlighting the epithelial component.

Two months after surgery, patient lies with partial improvement of symptoms and remains in clinical follow up. According to the follow up of Kuo's $\operatorname{cases}^{(3)}$, the patients showed improvement of symptoms gradually after surgery and had remission of symptoms between two and four years after surgery. In the series of Moran and Suster ${ }^{(5)}$, there was follow-up of eight of the 10 patients reported. Six of them died from causes unrelated to thymoma, such as renal failure, congestive heart failure and pulmonary edema and two of these patients survived asymptomatic for one to six years after surgical resection.

Pathogenesis of the sclerosing thymoma is uncertain. The first hypothesis was described by $\mathrm{KuO}^{(3)}$ and is based on a possible spontaneous phenomenon of regression and sclerosis possibly associated with infarct through the interruption of vascular flow or apoptosis. Another hypothesis is that these sclerosing tumor originate from "ancient" thymoma whose pre-existing collagen bands coalesce, remaining some areas preserved.

In our view, it is a healing process induced by previous cell injury that could initiate, for example, from the interruption of vascular flow and consequent necrosis. The necrotic cells and their contents disappear by phagocytoses and enzymatic digestion by leukocytes. The migration of fibroblasts into the injury site is guided by chemokines and their subsequent proliferation is triggered by several growth factors, macrophages being the main source of these factors ${ }^{(4,8)}$.

The number of proliferating fibroblasts and new vessels decreases, however, the fibroblasts progressively assume a more synthetic phenotype, and hence there is increased deposition of extracellular matrix and collagen synthesis by fibroblasts. As the scar matures, vascular regression eventually transforms the highly vascularized granulation tissue into a pale, largely avascular scar. Other findings, such as dystrophic calcification and bone metaplasia, also represent evidence of previous cell injury ${ }^{(1)}$. 
Nevertheless, regardless cause of these changes, it is important to consider thymomas in the differential diagnosis of hyalinized or sclerotic lesions of the anterior mediastinum. These lesions include sclerosing mediastinitis, solitary fibrous tumors, and lymphoma with prominent sclerosis ${ }^{(2,6)}$.
Sclerosing thymoma is a rare tumour exhibiting the feature of a conventional thymoma, but with exuberant collagen-rich stroma. The histopathologic features of thymomas are very important and can cause problems in diagnosis with small mediastinoscopic biopsy specimens.

\section{References}

1. DARBY, I. A.; HEWITSON, T. D. Fibroblast differentiation in wound healing and fibrosis. Int Rev Cytol, v. 257, p. 143-79, 2007.

2. HIROSHI, S.; MOTOHIRO, Y.; EISAKU, K.; SHIGEKI, S.; NORIHIRO, T. Solitary fibrous tumor of the mediastinum. Gen Thorac Cardiovasc Surg, v. 58, p. 205-8, 2010.

3. KUO T. Sclerosing thymoma: a possible phenomenon of regression. Histopathology, v. 25, p. 289-91, 1994.

4. MARTINEZ, F. O.; SICA, A.; MANTOVANI, A.; LOCATI, M. Macrophage activation and polarization. Front Biosci, v. 13, p. 453-61, 2008.

5. MORAN, C. A.; SUSTER, S. Ancient (sclerosing) thymomas: a clinicopathologic study of 10 cases. Am J Clin Pathol, v. 121, p. 867-71, 2004.

6. TOSHIO, M.; MAKOTO, T.; RYOJI, Y.; RYU, N.; HIROHITO, T. Sclerosing mediastinitis mimicking anterior mediastinal tumor. Ann Thorac Surg, v. 88, p. 293-5, 2009.

7. TRAVIS, W. D.; BRAMBILLA, E.; MULLER-HERMELINK, H. K.; HARRIS, C. C. Rare thymomas in pathology and genetics of tumours of the lung, pleura, thymus and heart-World Health Organization classification of tumours. Lyon: IARC Press, 2004.

8. WERNER, S.; GROSE, R. Regulation of wound healing by growth factors and cytokines. Physiol Rev, v. 83, n. 3, p. 835-70, 2003. 